\title{
The effect of poultry manure and inorganic fertilizer on the arbuscular mycorrhiza in coconut
}

\author{
T. G. Karunasinghe ${ }^{1}$, W. C. Fernando ${ }^{2}$ and L. R. Jayasekera ${ }^{1 *}$ \\ ${ }^{\prime}$ Department of Botany, Faculty of Science, University of Kelaniya, Kelaniya. \\ 2 Coconut Research Institute, Bandirippuwa Estate, Lunuwila.
}

The arbuscular mycorrhizal fungi (AMF) are known as beneficial soil micro-organisms and they have been widely used as bio-fertilizers to improve seedling vigor in plant nurseries ${ }^{1,2}$ as well as in fields to restore the soil fertility and thereby to improve crop growth ${ }^{3,4}$. Coconut (Cocos nucifera L.) is an important food and cash crop in most tropical regions of the world. Unfortunately, the coconut industry has recently faced a major problem in yield reduction. It was speculated that the underlying causes for this may be the depletion of soil physicochemical and biological properties of the plantations ${ }^{5}$. The current study was conducted as a preliminary investigation to estimate and compare natural AMF colonization and soil spore densities in coconut palms located in the low country intermediate zone.

The study was conducted at the Rathmalagara experimental plantation of the Coconut Research Institute (CRI) in a randomized complete block design where three blocks were treated annually viz., no fertilizer application (NT); inorganic fertilizer mixture comprising $800 \mathrm{~g}$ of urea, $1600 \mathrm{~g}$ of muriate of potash, $900 \mathrm{~g}$ of Eppawala rock phosphate and $1 \mathrm{~kg}$ of dolomite per palm per year, the recommended inorganic fertilizer mixture (IFM) for adult coconut palms; and poultry manure $(30 \mathrm{~kg})$ with a supplement of muriate of potash $(0.25 \mathrm{~kg})$ per palm (PL). One year after fertilization, soil $(12 \mathrm{~cm}$ depth) and actively growing root samples were taken in triplicate from the rhizosphere of selected palms in each treatment in each block. Actively growing roots were cleaned and stained with $0.1 \%$ Trypan blue, then percentage of root colonization, arbuscules and number of vesicles were determined $^{3}$. The spores were separated from soil samples according to the wet sieving method and counted ${ }^{3}$. Soil samples were analyzed for selected physicochemical properties namely, $\mathrm{pH}$, electrical conductivity (EC), organic carbon (OC), $\mathrm{NH}_{4}^{+}-\mathrm{N}, \mathrm{NO}_{3}^{-}-\mathrm{N}$ and available phosphorus $\left(\mathrm{P}_{\mathrm{a}}\right)$ using standard methods $\mathrm{s}^{6}$.

Table 1: Means with standard errors of root colonization, arbuscules, number of vesicles of arbuscular mycorrhiza, coconut yield in non treated (NT), inorganic fertilizer mixture (IFM) applied and poultry manure (PL) applied coconut palms.

\begin{tabular}{lccccc}
\hline Treatment & $\begin{array}{c}\text { Percentage of } \\
\text { root colonization }\end{array}$ & $\begin{array}{c}\text { Percentage of } \\
\text { arbuscules }\end{array}$ & $\begin{array}{c}\text { Number of } \\
\text { vesicles/ } 1 \mathrm{~cm} \\
\text { root length }\end{array}$ & $\begin{array}{c}\text { Total number } \\
\text { of spores } / 1 \mathrm{~g} \\
\text { Soil }\end{array}$ & $\begin{array}{c}\text { Coconut yield } \\
\text { nuts/palm/month }\end{array}$ \\
\hline NT & $46.9^{\mathrm{a}} \pm 1.4$ & $28.5^{\mathrm{a}} \pm 1.2$ & $1.4^{\mathrm{b}} \pm 0.1$ & $204.1^{\mathrm{ab}} \pm 12.8$ & $6.4^{\mathrm{a}} \pm 0.58$ \\
IFM & $29.0^{\mathrm{b}} \pm 3.2$ & $9.5^{\mathrm{b}} \pm 1.3$ & $2.5^{\mathrm{a}} \pm 0.4$ & $261.2^{\mathrm{a}} \pm 29.5$ & $8.0^{\mathrm{b}} \pm 0.37$ \\
PL & $42.0^{\mathrm{a}} \pm 1.2$ & $13.1^{\mathrm{b}} \pm 0.5$ & $0.9^{\mathrm{b}} \pm 0.1$ & $151.6^{\mathrm{b}} \pm 23.1$ & $11.6^{\mathrm{c}} \pm 0.29$ \\
Significance & $* * *$ & $* * *$ & $* * *$ & $*$ & $* *$ \\
LSD $(\alpha=0.05)$ & 7.49 & 3.69 & 0.79 & 79.14 & 0.75 \\
\hline
\end{tabular}

Means with different letters within columns are significantly different, ${ }^{*}$ at $\mathrm{p} \leq 0.05,{ }^{* * *}$ at $\mathrm{p} \leq 0.001$; LSD: least significant difference. 
Table 2: Means and standard errors of soil physico-chemical parameters in non treated (NT), inorganic fertilizer mixture (IFM) applied and poultry manure (PL) applied coconut palms.

\begin{tabular}{|c|c|c|c|c|c|c|}
\hline \multirow{2}{*}{ Treatment } & \multicolumn{6}{|c|}{ Soil physico-chemical parameters } \\
\hline & $\mathrm{pH}$ & $\begin{array}{c}\mathrm{EC} \\
(\mu \mathrm{mho} / \mathrm{cm})\end{array}$ & $\begin{array}{c}\text { Organic } \\
\text { carbon (\%) }\end{array}$ & $\begin{array}{l}\mathrm{NH}_{4}^{+}-\mathrm{N} \\
(\mathrm{mg} / \mathrm{kg}\end{array}$ & $\begin{array}{l}\mathrm{NO}_{3}^{-}-\mathrm{N} \\
(\mathrm{mg} / \mathrm{kg}\end{array}$ & $\begin{array}{c}\text { Available } \\
\text { phosphorus } \\
(\mathrm{mg} / \mathrm{kg})\end{array}$ \\
\hline NT & $6.0^{c} \pm 0.1$ & $36.5^{b} \pm 2.3$ & $0.8^{\mathrm{b}} \pm 0.03$ & $4.3^{\mathrm{a}} \pm 0.4$ & $2.2^{\mathrm{a}} \pm 0.4$ & $146.6^{\mathrm{c}} \pm 35.4$ \\
\hline IFM & $6.5^{\mathrm{b}} \pm 0.1$ & $32.4^{b} \pm 1.1$ & $0.7^{\mathrm{b}} \pm 0.04$ & $2.3^{b} \pm 0.6$ & $1.9^{\mathrm{a}} \pm 0.5$ & $281.0^{\mathrm{b}} \pm 56.2$ \\
\hline PL & $7.0^{\mathrm{a}} \pm 0.1$ & $79.7^{a} \pm 9.4$ & $1.4^{\mathrm{a}} \pm 0.21$ & $4.3^{\mathrm{a}} \pm 0.6$ & $2.2^{\mathrm{a}} \pm 0.6$ & $951.5^{\mathrm{a}} \pm 137.4$ \\
\hline Significance & $* * *$ & $* * *$ & $* *$ & $*$ & ns & $* * *$ \\
\hline $\operatorname{LSD}(\alpha=0.05) \mathrm{s}$ & 0.24 & 19.49 & 0.43 & 1.80 & 1.81 & 228.36 \\
\hline
\end{tabular}

Means with different letters within columns are significantly different, * at $\mathrm{p} \leq 0.05, * * *$ at $\mathrm{p} \leq 0.001$;

LSD: least significant difference; ns - no significance.

The AMF present in the coconut roots in all three treatments were identified as Glomus spp ${ }^{7}$. Highly significant differences $(\mathrm{p}<0.001)$ were observed between treatments for AMF root colonization, arbuscules, number of vesicles and total number of spores in soil (Table 1). $\mathrm{PL}$ applied soil showed significantly higher $\mathrm{NH}_{4}^{+}-\mathrm{N}, \mathrm{P}_{\mathrm{a}}$ and organic carbon than the IFM treated soil (Table 2). In the current study, soil nutrient status has increased with the application of PL than the application of IFM. Low amount of inorganic nutrients in IFM treated soil could be due to the reason that the added inorganic fertilizers are lost rapidly by several soil processes. However, poultry manure treatment has not increased total AMF root colonization and soil spores when compared with untreated (NT) coconut palms. Application of IFM or inorganic nutrients as a supplement has decreased the AMF colonization in coconut roots. This is probably because of the adverse effects of high concentration of nutrients and salts in inorganic fertilizers ${ }^{3,8,9}$. Also in the PL treatments, both the $\mathrm{P}_{\mathrm{a}}$ and the AMF colonization were high. This is not in agreement with a previous study ${ }^{9}$, where root colonization of AMF decreased when $\mathrm{P}_{\mathrm{a}}$ was high in the rhizosphere. However, since the level of organic carbon is highest in the PL treated soil, it can be assumed that the increased colonization could be due to the favourable conditions created by the application of organic manure, which facilitate the growth of roots as in other studies ${ }^{10,11}$. The $\mathrm{NH}_{4}^{+}-\mathrm{N}$ levels of the rhizosphere soil of the palms may have a stimulatory effect over colonization and arbuscule formation of AMF, probably indicating a relationship between AMF colonization, arbuscule formation and soil nitrogen levels as seen in previous studies $^{12,13}$. Therefore, it shows that AMF depend on the soil nutrient levels or the type of fertilizer applied to the coconut palms. Since AMF naturally colonize the coconut roots, AMF combine fertilizer management practice or AMF-friendly fertilizer application will be more effective for coconut palms to maintain their natural AMF colonization, and thereby to improve the nutrient uptake in eroded coconut lands.

\section{References}

1. Douds D.D., Nagahashi G., Pfeffer P.E., Kayser W.M. \& Reider C. (2005). On-farm production and utilization of mycorrhizal fungus inoculum. Canadian Journal of Plant Science 85: 15-21.

2. Davies F.T. Jr, Saraiva Grossi J.A., Carpio L. \& Estrada-Luna A.A. (2000). Colonization and growth effects of the mycorrhizal fungus Glomus intraradices in a commercial nursery container production system. Journal of Environmental Horticulture 18(4):247-251.

3. Brundrett M., Bougher N., Dell B., Grove T. \& Malajazuk N. (1996). Working with mycorrhizas in forestry and agriculture. Monograph 32, Australian Centre for International Agricultural Research, Canberra, Australia.

4. Chang D.C.N. (1994). What is the potential for management of vesicular-arbuscular mycorrhizae in horticulture? In: Management of Mycorrhizas in Agriculture and Forestry (Eds. D. Robson, L. Abbott \& N. Malajczuk) pp. 187190, Kluwer Academic Publishers, Dordrecht The Netherlands.

5. Ranasinghe C.S., Wijesekara R. \& Wimalasekara R. (2002). Rapid decline syndrome of coconut: preliminary report of a new condition. Palms 46(4): 167-171.

6. Black C.A., Evans D.D., White J.L., Ensminger L.E. \& Clerk F.E. (1965). Methods of soil analysis, Part 2. Chemical and microbiological properties-agronomy series, No. 9. American Society of Agronomy and American Society of Testing and Materials, Madison, WI, USA.

7. http://www.invam.caf.wvu.edu/cultures/cultureindex.htm

8. Huat O.K., Awang K., Hashim A. \& Majid N.M. (2002). Effect of fertilizer and vesicular-arbuscular mycorrhizas on the growth and photosynthesis of Azadirachta excelsa (Jack) Jacobs's seedlings. Forest Ecology and Management. 158(1-3): 51-58. 
9. Mosse B. (1963). Vesicular-arbuscular Mycorrhiza: an extreme form of fungal adaptation. In: Symbiotic Associations, $13^{\text {th }}$ Symposium of the Society for General Microbiology (Eds. P.S. Nutman \& B. Mosse), pp. 146170, Cambridge University Press, London, UK.

10. Labidi S., Nasr H., Zouaghi M. \& Wallander H. (2007). Effects of compost addition on extra-radical growth of arbuscular mycorrhizal fungi in Acacia tortilis spp. raddiana savanna in a pre-Saharan area. Applied Soil Ecology 35: 184-192.

11. Linderman R.G. \& Davis E.A. (2004). Evaluation of commercial inorganic and organic fertilizer effects on arbuscular mycorrhizae formed by Glomus intraradices. Horticulure Technology 14(2): 196-202.

12. Smith E., St. John B.J., Smith F.A. \& Nicholas D.J.D. (1985). Activity of glutamine synthetase and glutamate dehydrogenase in Trifolium subterraneum L. and Allium cepa L: effects of mycorrhizal infection and phosphate nutrition. New Phytologist 99: 211-227.

13. Hepper C.M. (1983). The effect of nitrate and phosphate on the vesicular-arbuscular mycorrhizal infection of lettuce. New Phytologist 92: 389-39. 